\title{
The contribution of dark-green leafy vegetables to total micro- nutrient intake of two- to five-year-old children in a rural setting ${ }^{\#}$
}

\author{
Mieke Faber ${ }^{1 *}$, Paul J van Jaarsveld ${ }^{1}$ and Ria Laubscher ${ }^{2}$ \\ ${ }^{1}$ Nutritional Intervention Research Unit, Medical Research Council, PO Box 19070, Tygerberg 7505, South Africa \\ ${ }^{2}$ Biostatistics Unit, Medical Research Council, PO Box 19070, Tygerberg 7505, South Africa
}

\begin{abstract}
This study determined the contribution of dark-green leafy vegetables (DGLV) to total micronutrient intake of two- to fiveyear-old children residing in two neighbouring rural villages in KwaZulu-Natal where production and consumption of these vegetables were promoted. A repeated cross-sectional study that included five repeated $24 \mathrm{~h}$ dietary recalls per study period was done during February ( $\mathrm{n}=79)$, May $(\mathrm{n}=74)$, August $(\mathrm{n}=75)$ and November $(\mathrm{n}=78)$ of 2005 by interviewing the caregivers. Consumption of spinach (mostly Swiss chard) and imifino (a collective term for various dark-green leaves) complemented each other, with imifino being consumed mostly during the first and last quarter of the year, and spinach (mostly Swiss chard) during the $3^{\text {rd }}$ quarter. The proportion of children who consumed DGLV during the $5 \mathrm{~d}$ recall period ranged from $36 \%$ (May survey) to $86 \%$ (February survey), and the average number of times that children consumed it ranged from 1.4 (May survey) to 2.2 (February survey). The average portion size consumed was approximately $1 / 2 \mathrm{cup}$ ( $87 \pm 56 \mathrm{~g}$ for spinach; $87 \pm 38 \mathrm{~g}$ for imifino). For children consuming DGLV, these vegetables contributed significantly to dietary intake of calcium (21 to $39 \%$ of total intake), iron (19 to $39 \%$ ), vitamin A (42 to $68 \%$ ) and riboflavin (9 to $22 \%$ ).

In conclusion, DGLV made a significant contribution towards total nutrient intake of the children for several of the micronutrients. This contribution can potentially be increased should these vegetables be consumed more frequently and by a larger proportion of the children.
\end{abstract}

Keywords: dark-green leafy vegetables, dietary intake, micronutrients, children, rural, South Africa

\section{Introduction}

In South Africa $33 \%$ of preschool children are vitamin A deficient, $21 \%$ are anaemic and $10 \%$ are iron depleted (Labadarios et al., 1995). The great majority of one- to nine-year-old children consume a diet deficient in energy and of poor nutrient density (Labadarios et al., 2000). With regard to the anthropometric status of South African preschool children, stunting is the major problem $(23 \%)$, while $9 \%$ are underweight and 3\% are wasted (Labadarios et al., 1995). Nutritional deficiencies in energy and protein, as well as iodine, iron, zinc and vitamin A can contribute to poor growth (WHO, 1999). Allen (1994) reviewed the literature on nutritional influences on linear growth and concluded that poor growth may be a consequence of multiple deficiencies that result when children consume diets of poor nutritional quality.

Rural communities in South Africa are nutritionally more vulnerable than those in the urban areas (Labadarios et al., 1995; Labadarios et al., 2000). A fundamental strategy to address micronutrient deficiencies in resource-poor communities is to increase the availability of, access to, and ultimately consumption of foods that are rich sources of micronutrients. This can potentially be achieved through food production at household level. One of the recommendations of the National Food Consumption Survey (NFCS) of 1999 was that the contribution that

\footnotetext{
Revised version. Originally presented at the International Symposium on the Nutritional Value and Water Use of Indigenous Crops for Improved Livelihoods held on 19 and 20 September 2006 at the University of Pretoria in Pretoria, South Africa

* To whom all correspondence should be addressed.

邑 +2721 938-0404; fax: +2721 9380321; e-mail: mieke.faber@mrc.ac.za
}

home-grown crops and livestock can make to children's diet should be recognised and appreciated and that growing crops at home should be promoted as feasible and appropriate (Labadarios et al., 2000).

Crop production systems should aim to increase the use of under-exploited natural resources such as traditional food crops (FAO, 1997). African leafy vegetables grow on soils of limited fertility, are relatively drought tolerant, provide good ground cover, and can be harvested within a short period of time (Shiundu, 2002).

The NFCS of 1999 showed that green leafy vegetables were the $16^{\text {th }}$ most frequently consumed food item for one- to nineyear-old South African children (12\% of the children consumed it during the recall period). The highest consumption was in Limpopo Province (previously known as the Northern Province), with green leaves being the $4^{\text {th }}$ most frequently consumed food item and $46 \%$ of the children consumed it during the recall period (Labadarios et al., 2000). A smaller study in Limpopo showed that green leafy vegetables were the $5^{\text {th }}$ most frequently consumed food item of the adult population (Steyn et al., 2001a). Regular adult consumers of wild, green leafy vegetables in Limpopo were found to eat it at least once or twice per week and the cooked portion sizes commonly ranged from 45 to $105 \mathrm{~g}$, to 180 to 270 g (Nesamvuni et al., 2001; Steyn et al., 2001b). Amaranthus hybridus L. and Amaranthus thunbergii were the most commonly eaten plants (Steyn et al., 2001b). In Venda (the most northerly region of Limpopo Province) it was found that harvesting of the leaves is mainly during summer and the surplus is stored in either a dried-cooked or dried-raw form for at least six months (Nesamvuni et al., 2001).

In contrast to the findings in Limpopo Province, the NFCS of 1999 showed that green leafy vegetables were only the $20^{\text {th }}$ 
most frequently consumed food item for one- to nine-year-old children in KwaZulu-Natal (Labadarios et al., 2000). In a project undertaken by the Medical Research Council, production and consumption of dark-green leafy vegetables and yellow/orangefleshed vegetables were promoted in a rural village in KwaZuluNatal (Faber et al., 2001).

In view of the potentially important contribution that darkgreen leafy vegetables can make towards the micronutrient intake of children, it appeared important to quantify the contribution of dark-green leafy vegetables to total micronutrient intake in children. Therefore, the aim of the present study was to determine the contribution of dark-green leafy vegetables to total micronutrient intake of two- to five-year old children. An existing data set was used from a study that looked at the effect of seasonality on vitamin A intake in Ndunakazi and Bhasobha, two neighbouring rural villages in the Valley of a Thousand Hills in KwaZulu-Natal, South Africa, where production and consumption of these vegetables were promoted.

\section{Materials and methods}

\section{Population}

The population density in the study areas is low and the households are scattered over a large mountainous area. The Ndunakazi village, for example, is estimated to be $11 \mathrm{~km}$ long and $1 \mathrm{~km}$ wide with approximately 200 households and, on average, 8 persons per household. The lack of health facilities within the area prompted the implementation of community-based growth monitoring activities in 1995 (Faber et al., 1998). The high prevalence of vitamin A deficiency (45.9\%) of preschool children in the area (Oelofse et al., 1999) prompted the establishment of a home-garden project that focused on $\beta$-carotene-rich vegetables and fruit. Demonstration gardens within the village were used as training centres for crop production. The community-based growth-monitoring activities were used as platform to promote the production of $\beta$-carotene-rich vegetables and fruit for household consumption in Ndunakazi since 1999 and in Bhasobha since 2001.

Evaluation of the project in Ndunakazi showed that the intake of yellow/orange-fleshed and dark-green leafy vegetables increased, and as a result the intake of vitamin A and various other essential micronutrients (e.g. calcium, iron and vitamin C) increased (Faber et al., 2002a). This had a positive effect on the vitamin A status of the children, as reflected in higher mean serum retinol concentrations (Faber at al. 2002b).

Dark-green leafy vegetables that are consumed in this area are spinach (mostly Swiss Chard) and imifino, which is a collective term for various dark-green leaves that is eaten as a vegetable; the leaves either grow wild or come from vegetables such as pumpkin, beetroot and sweetpotato.

\section{Dietary intake of two- to five-year-old children}

A repeated cross-sectional dietary study was done during February $(n=79)$, May $(n=74)$, August $(n=75)$ and November $(n=78)$ of 2005. Caregivers of registered two- to five-year-old children of the community-based growth monitoring project were interviewed by experienced nutrition monitors in their own language (Zulu). Caregivers of 86 children were interviewed. Only caregivers who were able and willing to be interviewed five consecutive days were included. Because of logistics not all the children were included on all four occasions (74 to 79 children/month). The mothers gave their consent after the purpose and the nature of the study were explained to them. The Ethics Committee of the Medical Research Council approved the study.

Dietary intake was quantified by five consecutive repeated $24 \mathrm{~h}$ recalls. The interviews were done from Monday to Friday. The period covered by the $24 \mathrm{~h}$ dietary recall included one weekend and four week days (Sunday to Thursday). Fresh food, plastic food models, household utensils, and three-dimensional sponge models were used to quantify and record food consumption of the previous day. In addition, dry oats was used to quantify portion sizes of certain food items, especially cooked food. The caregiver used the dry oats to indicate the quantity resembling the amount of food that the child had eaten. The fieldworker quantified the dry oats with a measuring cup. Food intake reported in household measures was converted into weight using the MRC Food Quantities Manual (Langenhoven et al., 1991a). The SAS software package (Version 9.1; SAS Institute Inc., Cary, NC) was used to convert food intake to macro- and micronutrients, using the MRC Food Composition Tables (Langenhoven et al., 1991b) as the food database. Dark-green leafy vegetables provide vitamins $\mathrm{A}$ and $\mathrm{C}$, riboflavin, folic acid, iron, calcium and magnesium (Warren, 2001). For these micronutrients, the contribution of dark-green leafy vegetables, namely spinach and imifino, to total intake was calculated and is expressed as a percentage of total intake.

The estimated average requirement (EAR) of the dietary reference intakes (DRIs) published by the Institute of Medicine (1997, 1998, 2000) was used as reference value for dietary adequacy. The EAR is the average daily nutrient intake amount estimated to meet the requirement of half the population. There is no EAR for calcium; adequate intake (AI) was used as reference value for calcium. Dietary intake for the group is considered nutritionally adequate if the mean intake for the group is at or above the AI.

\section{Results}

\section{Dietary intake of two- to five-year old children}

The frequency of consumption of dark-green leafy vegetables is shown in Table 1. Imifino was consumed mostly during the $1^{\text {st }}$ (represented by February) and last (represented by November) quarters of the year, and spinach during the $3^{\text {rd }}$ quarter (represented by August). Consumption during the $2^{\text {nd }}$ quarter (represented by May) was low for both imifino and spinach. The average portion size consumed by the children was approximately $1 / 2$ cup $(87 \pm 56 \mathrm{~g}$ for spinach and $87 \pm 38 \mathrm{~g}$ for imifino).

Total micronutrient intake, micronutrient intake from darkgreen leafy vegetables and the contribution of dark-green leafy vegetables to total intake (expressed as a percentage of the total nutrient intake) are given in Table 2. Micronutrient intake is given as the median and the inter-quartile range, namely Q1 (25 $5^{\text {th }}$ percentile) and Q3 ( $75^{\text {th }}$ percentile). The median intake for calcium was below the AI, indicating an inadequate calcium intake. The percentage of children with an intake below the EAR varied: magnesium ( $0 \%$ ), iron ( 0 to $4 \%$ ), vitamin $\mathrm{C}$ (0 to $15 \%$ ), riboflavin (6 to $32 \%$ ) and vitamin A (19 to $44 \%$ ).

In the May survey, only $36 \%$ of the children consumed darkgreen leafy vegetables during the $5 \mathrm{~d}$ recall period. This explains why the median intake from dark-green leafy vegetables is zero for all the nutrients.

Nutrient intake analysis was repeated, including only children who consumed dark-green leafy vegetables during the $5 \mathrm{~d}$ recall period (consumers) (Table 3). For children consuming dark-green leafy vegetables, these vegetables contributed 


\begin{tabular}{|c|c|c|c|c|}
\hline \multicolumn{5}{|c|}{$\begin{array}{c}\text { TABLE } 1 \\
\text { Consumption of dark-green leafy vegetables by two- to five-year } \\
\text { old children during February, May, August and November } 2005 \text { as } \\
\text { determined by the } 5 \mathrm{~d} \text { repeated } 24 \mathrm{~h} \text { recall }\end{array}$} \\
\hline \multirow[t]{2}{*}{ Food } & Feb & May & Aug & Nov \\
\hline & $(n=78)$ & $(n=74)$ & $(n=75)$ & $(n=78)$ \\
\hline \multicolumn{5}{|c|}{ Proportion of children who consumed dark-green leafy vegetables } \\
\hline Type of green leafy vegetable & \multicolumn{4}{|c|}{ Proportion of children } \\
\hline All dark-green leafy vegetables ${ }^{a}$ & $86 \%$ & $36 \%$ & $59 \%$ & $78 \%$ \\
\hline Imifino $^{\mathrm{b}}$ & $86 \%$ & $22 \%$ & $20 \%$ & $72 \%$ \\
\hline Spinach & $0 \%$ & $15 \%$ & $49 \%$ & $14 \%$ \\
\hline \multicolumn{5}{|c|}{ Total number of times of dark-green leafy vegetable consumption reported over $5 \mathrm{~d}$} \\
\hline Type of green leafy vegetable & \multicolumn{4}{|c|}{ Number of times reported } \\
\hline Imifino $^{\mathrm{b}}$ & 149 & 24 & 25 & 105 \\
\hline Spinach & 0 & 15 & 65 & 16 \\
\hline \multicolumn{5}{|c|}{ Frequency of dark-green leafy vegetable consumption per $5 \mathrm{~d}$ per child ${ }^{\mathrm{c}}$} \\
\hline Type of green leafy vegetable & \multicolumn{4}{|c|}{ Frequency of consumption ${ }^{c}$} \\
\hline All dark-green leafy vegetables ${ }^{\mathrm{a}}$ & 2.2 & 1.4 & 2.0 & 2.0 \\
\hline
\end{tabular}

\begin{tabular}{|c|c|c|c|c|c|c|c|c|c|c|}
\hline \multicolumn{11}{|c|}{$\begin{array}{c}\text { TABLE } 2 \\
\text { Total micronutrient intake and the contribution of dark-green leafy vegetables to total micronutrient } \\
\text { intake of two- to five-year old children during February, May, August and November } 2005 \text { as determined } \\
\text { by a } 5 \mathrm{~d} \text { repeated } 24 \mathrm{~h} \text { dietary recall }\end{array}$} \\
\hline \multicolumn{3}{|l|}{\begin{tabular}{|l|} 
Nutrient \\
\end{tabular}} & \multicolumn{2}{|c|}{ Feb $(n=79)$} & \multicolumn{2}{|c|}{ May $(n=74)$} & \multicolumn{2}{|c|}{ Aug (n=75) } & \multicolumn{2}{|c|}{ Nov $(n=78)$} \\
\hline & EAR & & Median & Q1; Q3 & Median & Q1; Q3 & Median & Q1; Q3 & Median & Q1; Q3 \\
\hline \multirow{3}{*}{$\begin{array}{l}\text { Calcium } \\
(m g)\end{array}$} & \multirow{3}{*}{$\begin{array}{l}500^{\mathrm{a}} \\
800^{\mathrm{b}}\end{array}$} & total & 212 & $(162 ; 262)$ & 184 & $(127 ; 229)$ & 214 & $(179 ; 268)$ & 294 & $(219 ; 368)$ \\
\hline & & DGLV & 70 & $(28 ; 121)$ & 0 & $(0 ; 27)$ & 26 & $(0 ; 54)$ & 70 & $(28 ; 112)$ \\
\hline & & $\%$ DGLV & 32 & $(17 ; 49)$ & 0 & $(0 ; 14)$ & 8 & $(0 ; 21)$ & 23 & $(11 ; 31)$ \\
\hline \multirow{3}{*}{$\begin{array}{l}\text { Iron } \\
(m g)\end{array}$} & \multirow{3}{*}{$\begin{array}{l}3.0^{\mathrm{c}} \\
4.1^{\mathrm{d}}\end{array}$} & total & 6.7 & $(5.3 ; 8.6)$ & 5.3 & $(4.6 ; 6.3)$ & 6.4 & $(5.7 ; 8.5)$ & 9.1 & $(7.2 ; 11.8)$ \\
\hline & & DGLV & 2.2 & $(0.90 ; 3.9)$ & 0 & $(0 ; 0.7)$ & 0.7 & $(0 ; 1.4)$ & 2.2 & $(0.8 ; 3.6)$ \\
\hline & & $\%$ DGLV & 32 & $(18 ; 46)$ & 0 & $(0 ; 15)$ & 10 & $(0 ; 20)$ & 23 & $(14 ; 35)$ \\
\hline \multirow{3}{*}{$\begin{array}{l}\text { Magnesium } \\
(\mathrm{mg})\end{array}$} & \multirow{3}{*}{$\begin{array}{c}65^{\mathrm{c}} \\
110^{\mathrm{d}}\end{array}$} & total & 202 & $(170 ; 231)$ & 187 & $(164 ; 217)$ & 236 & $(181 ; 302)$ & 276 & $(208 ; 358)$ \\
\hline & & DGLV & 30 & $(12 ; 51)$ & 0 & $(0 ; 17)$ & 13 & $(0 ; 28)$ & 33 & $(12 ; 44)$ \\
\hline & & $\%$ DGLV & 14 & $(7 ; 21)$ & 0 & $(0 ; 10)$ & 6 & $(0 ; 13)$ & 11 & $(7 ; 18)$ \\
\hline \multirow{3}{*}{$\begin{array}{l}\text { Vitamin A } \\
(R E)\end{array}$} & \multirow{3}{*}{$\begin{array}{l}210^{\mathrm{c}} \\
275^{\mathrm{d}}\end{array}$} & total & 401 & $(245 ; 562)$ & 257 & $(129 ; 423)$ & 281 & $(141 ; 459)$ & 400 & $(306 ; 668)$ \\
\hline & & DGLV & 190 & (76; 328) & 0 & $(0 ; 156)$ & 124 & $(0 ; 241)$ & 219 & $(76 ; 313)$ \\
\hline & & $\%$ DGLV & 55 & $(22 ; 72)$ & 0 & $(0 ; 34)$ & 29 & $(0 ; 71)$ & 46 & $(20 ; 67)$ \\
\hline \multirow{3}{*}{$\begin{array}{l}\text { Riboflavin } \\
(m g)\end{array}$} & \multirow{3}{*}{$\begin{array}{l}0.4^{\mathrm{c}} \\
0.5^{\mathrm{d}}\end{array}$} & total & 0.64 & $(0.43 ; 0.98)$ & 0.61 & $(0.36 ; 0.90)$ & 0.69 & $(0.51 ; 1.01)$ & 0.90 & $(0.65 ; 1.13)$ \\
\hline & & DGLV & 0.11 & $(0.04 ; 0.19)$ & 0 & $(0 ; 0.05)$ & 0.04 & $(0 ; 0.09)$ & 0.11 & $(0.04 ; 0.18)$ \\
\hline & & $\%$ DGLV & 16 & $(5 ; 37)$ & 0 & $(0 ; 6)$ & 3 & $(0 ; 11)$ & 12 & $(4 ; 22)$ \\
\hline \multirow{3}{*}{$\begin{array}{l}\text { Folic acid } \\
(\mu g)\end{array}$} & \multirow{3}{*}{$\begin{array}{l}120^{\mathrm{c}} \\
160^{\mathrm{d}}\end{array}$} & total & 168 & $(133 ; 221)$ & 177 & $(133 ; 215)$ & 252 & $(200 ; 319)$ & 263 & $(199 ; 345)$ \\
\hline & & DGLV & 0 & $(0 ; 0)$ & 0 & $(0 ; 0)$ & 0 & $(0 ; 35)$ & 0 & $(0 ; 0)$ \\
\hline & & $\%$ DGLV & 0 & $(0 ; 0)$ & 0 & $(0 ; 0)$ & 0 & $(0 ; 15)$ & 0 & $(0 ; 0)$ \\
\hline \multirow{3}{*}{$\begin{array}{l}\text { Vitamin C } \\
(m g)\end{array}$} & \multirow{3}{*}{$\begin{array}{l}13^{\mathrm{c}} \\
22^{\mathrm{d}}\end{array}$} & total & 28 & $(19 ; 34)$ & 42 & $(33 ; 58)$ & 47 & $(36 ; 72)$ & 54 & $(44 ; 69)$ \\
\hline & & DGLV & 2 & $(1 ; 4)$ & 0 & $(0 ; 2)$ & 1 & $(0 ; 3)$ & 3 & $(1 ; 4)$ \\
\hline & & $\%$ DGLV & 8 & $(4 ; 16)$ & 0 & $(0 ; 4)$ & 2 & $(0 ; 8)$ & 4 & $(2 ; 8)$ \\
\hline
\end{tabular}

$E A R=$ estimated average requirement

$Q 1=25^{\text {th }}$ percentile, $Q 3=75^{\text {th }}$ percentile

$\mu g=$ microgram

$m g=$ milligram

$R E=$ retinol equivalent, $1 R E=1 \mu \mathrm{g}$ retinol $=6 \mu \mathrm{g} \beta$-carotene

$D G L V=$ dark-green leafy vegetables
$\% D G L V=$ nutrient from DGLV expressed as a percentage of total intake

${ }^{a}$ Adequate intake (AI) for age $2 \& 3$ years (Institute of Medicine, 1997)

${ }^{b}$ AI for age $4 \& 5$ years (Institute of Medicine, 1997)

${ }^{c}$ EAR for age 2\&3 years (Institute of Medicine 1997, 1998, 2000)

${ }^{d}$ EAR for age $4 \& 5$ years (Institute of Medicine 1997, 1998, 2000) 


\begin{tabular}{|c|c|c|c|c|c|c|c|c|c|c|}
\hline \multicolumn{11}{|c|}{$\begin{array}{l}\text { TABLE } 3 \\
\text { Total micronutrient intake and the contribution of dark-green leafy vegetables to total micronutrient intake of two- } \\
\text { to five-year old children during February, May, August and November } 2005 \text { as determined by the } 5 \mathrm{~d} \text { repeated } 24 \mathrm{~h} \\
\text { dietary recall for consumers only (Consumers are defined as children who ate DGLV during the recall period) }\end{array}$} \\
\hline \multicolumn{3}{|c|}{ Nutrient } & \multicolumn{2}{|c|}{ Feb $(n=67)$} & \multicolumn{2}{|c|}{ May $(n=27)$} & \multicolumn{2}{|c|}{ Aug ( $n=44)$} & \multicolumn{2}{|c|}{ Nov $(n=61)$} \\
\hline & EAR & & \begin{tabular}{|l|} 
Median \\
\end{tabular} & Q1; Q3 & \begin{tabular}{|l|} 
Median \\
\end{tabular} & Q1; Q3 & Median & Q1; Q3 & Median & Q1; Q3 \\
\hline \multirow{3}{*}{$\begin{array}{l}\text { Calcium } \\
(m g)\end{array}$} & \multirow{3}{*}{$\begin{array}{l}500^{\mathrm{a}} \\
800^{\mathrm{b}}\end{array}$} & total & 223 & $(185 ; 265)$ & 212 & $(173 ; 263)$ & 198 & $(174 ; 289)$ & 312 & $(246 ; 391)$ \\
\hline & & DGLV & 84 & $(56 ; 136)$ & 56 & $(26 ; 61)$ & 45 & $(27 ; 56)$ & 81 & $(56 ; 121)$ \\
\hline & & $\%$ DGLV & 39 & $(25 ; 52)$ & 21 & $(13 ; 33)$ & 21 & $(15 ; 31)$ & 27 & $(20 ; 36)$ \\
\hline \multirow{3}{*}{$\begin{array}{l}\text { Iron } \\
(m g)\end{array}$} & \multirow{3}{*}{$\begin{array}{l}3.0^{\mathrm{c}} \\
4.1^{\mathrm{d}}\end{array}$} & total & 7.1 & $(5.6 ; 8.8)$ & 6.3 & $(4.8 ; 6.3)$ & 6.2 & $(5.2 ; 8.2)$ & 9.4 & $(7.0 ; 12.0)$ \\
\hline & & DGLV & 2.7 & $(1.8 ; 4.3)$ & 1.8 & $(0.7 ; 1.9)$ & 1.4 & $(0.7 ; 1.7)$ & 2.6 & $(1.8 ; 3.9)$ \\
\hline & & $\%$ DGLV & 39 & $(27 ; 50)$ & 22 & $(14 ; 39)$ & 19 & $(13 ; 30)$ & 27 & 39) \\
\hline \multirow{3}{*}{$\begin{array}{l}\text { Magnesium } \\
(\mathrm{mg})\end{array}$} & \multirow{3}{*}{$\begin{array}{c}65^{\mathrm{c}} \\
110^{\mathrm{d}}\end{array}$} & total & 206 & $(171 ; 233)$ & 191 & $(164 ; 224)$ & 208 & $(173 ; 275)$ & 247 & $(205 ; 373)$ \\
\hline & & DGLV & 35 & $(24 ; 57)$ & 24 & $(16 ; 25)$ & 25 & $(17 ; 34)$ & 34 & $(25 ; 51)$ \\
\hline & & $\%$ DGLV & 18 & $(11 ; 24)$ & 12 & $(8 ; 15)$ & 13 & $(8 ; 16)$ & 13 & $(10 ; 20)$ \\
\hline \multirow{3}{*}{$\begin{array}{l}\text { Vitamin A } \\
(R E)\end{array}$} & \multirow{3}{*}{$\begin{array}{l}210^{c} \\
275^{d}\end{array}$} & total & 429 & $(257 ; 577)$ & 410 & $(268 ; 506)$ & 403 & $(287 ; 552)$ & 505 & $(350 ; 761)$ \\
\hline & & DGLV & 228 & $(152 ; 368)$ & 160 & $(152 ; 219)$ & 228 & $(156 ; 327)$ & 228 & $(162 ; 334)$ \\
\hline & & $\%$ DGLV & 62 & $(33 ; 75)$ & 42 & $(32 ; 63)$ & 68 & $(48 ; 78)$ & 57 & $(35 ; 69)$ \\
\hline \multirow{3}{*}{$\begin{array}{l}\text { Riboflavin } \\
(m g)\end{array}$} & \multirow{3}{*}{$\begin{array}{l}0.4^{\mathrm{c}} \\
0.5^{\mathrm{d}}\end{array}$} & total & 0.62 & $(0.43 ; 0.94)$ & 0.91 & $(0.70 ; 1.04)$ & 0.75 & $(0.60 ; 1.10)$ & 0.93 & $(0.74 ; 1.18)$ \\
\hline & & DGLV & 0.14 & $(0.09 ; 0.22)$ & 0.09 & $(0.05 ; 0.10)$ & 0.08 & $(0.05 ; 0.10)$ & 0.13 & $(0.09 ; 0.19)$ \\
\hline & & $\%$ DGLV & 22 & $(13 ; 36)$ & 9 & $(5 ; 16)$ & 10 & $(6 ; 19)$ & 15 & $(10 ; 24)$ \\
\hline \multirow{3}{*}{$\begin{array}{l}\text { Folic acid } \\
(\mu g)\end{array}$} & \multirow{3}{*}{$\begin{array}{l}120^{\mathrm{c}} \\
160^{\mathrm{d}}\end{array}$} & total & 168 & $(132 ; 206)$ & 157 & $(121 ; 205)$ & 238 & $(181 ; 287)$ & 235 & $(195 ; 323)$ \\
\hline & & DGLV & 0 & $(0 ; 0)$ & 0 & $(0 ; 27)$ & 28 & $(14 ; 58)$ & 0 & $(0 ; 0)$ \\
\hline & & $\%$ DGLV & 0 & $(0 ; 0)$ & 0 & $(0 ; 13)$ & 14 & $(7 ; 22)$ & 0 & $(0 ; 0)$ \\
\hline \multirow{3}{*}{$\begin{array}{l}\text { Vitamin C } \\
(m g)\end{array}$} & \multirow{3}{*}{$\begin{array}{l}13^{\mathrm{c}} \\
22^{\mathrm{d}}\end{array}$} & total & 28 & $(19 ; 34)$ & 38 & $(26 ; 57)$ & 41 & $(32 ; 57)$ & 53 & $(44 ; 67)$ \\
\hline & & DGLV & 3 & $(2 ; 4)$ & 2 & $(2 ; 3)$ & 3 & $(2 ; 4)$ & 3 & $(2 ; 4)$ \\
\hline & & \%DGLV & 10 & $(6 ; 16)$ & 5 & $(4 ; 7)$ & 6 & $(4 ; 12)$ & 6 & $(4 ; 9)$ \\
\hline
\end{tabular}

$E A R=$ estimated average requirement

$Q 1=25^{\text {th }}$ percentile, $Q 3=75^{\text {th }}$ percentile

$\mu \mathrm{g}=$ microgram

$m g=$ milligram

$R E=$ retinol equivalent, $1 R E=1 \mu \mathrm{g}$ retinol $=6 \mu \mathrm{g} \beta$-carotene

$D G L V=$ dark-green leafy vegetables

significantly to dietary intake of calcium (21 to 39\%), iron (19 to $39 \%$ ), vitamin A (42 to $68 \%$ ) and riboflavin (9 to $22 \%$ ).

\section{Discussion}

Consumption of spinach and imifino complemented each other, with imifino being consumed mostly during the $1^{\text {st }}$ and last quarter of the year (i.e. during the summer season in the study areas), and spinach during the $3^{\text {rd }}$ quarter (late winter/early spring). Consumption was lowest during the May (early winter) survey, with only $36 \%$ of the children consuming dark-green leafy vegetables during the $5 \mathrm{~d}$ recall period. The high consumption of imifino during the first and last quarter of the year is in line with a study in Ezigini, a rural community in KwaZulu-Natal, which showed that wild leafy vegetables are available in abundance from November to April (Modi et al., 2006), i.e. during the rainy season of the area.

It is often difficult to determine the nutritional contribution of wild plant foods to total dietary intake because of the lack of compositional data. We did not distinguish between all the different varieties of dark-green leafy vegetables and grouped the dark-green leafy vegetables as either spinach (mostly Swiss Chard) or imifino, as these were the food items included in the food composition data base. We used the 1991 food composition database for comparability with previous studies done in the same area. Nesamvuni et al. (2001) collected and analysed the ten most commonly consumed wild green leaves eaten in
$\% D G L V=$ nutrient from $D G L V$ expressed as a percentage of total intake ${ }^{a}$ Adequate intake (AI) for age $2 \& 3$ years (Institute of Medicine, 1997)

${ }^{b}$ AI for age $4 \& 5$ years (Institute of Medicine, 1997)

${ }^{c} E A R$ for age $2 \& 3$ years (Institute of Medicine 1997, 1998, 2000)

${ }^{d}$ EAR for age $4 \& 5$ years (Institute of Medicine 1997, 1998, 2000)

Venda and some of these values are incorporated into the 1998 edition of the South African food composition tables (Kruger et al., 1998). Nesamvuni et al (2001) collected only one sample for each type of leaf from one site. Food samples are typically heterogeneous and, as a result, a bigger sample size is usually needed to obtain a representative sample (Rodriguez-Amaya, 1999). Usually more than one random sample is collected during the growing season of the food in question and analysed.

The proportion of children who consumed dark-green leafy vegetables during the $5 \mathrm{~d}$ recall period ranged from 36\% (May survey) to $86 \%$ (February survey), and the average number of times that children consumed it ranged from 1.4 (May survey) to 2.2 (February survey). For children consuming dark-green leafy vegetables, these vegetables contributed significantly to dietary intake of calcium (21 to $39 \%$ ), iron (19 to 39\%), vitamin A (42 to $68 \%$ ) and riboflavin (9 to $22 \%$ ). These nutrients were all deficient in the diets of one- to nine-year-old South African children as determined in the NFCS of 1999 (Labadarios et al., 2000).

The biggest nutrient contribution of dark-green leafy vegetables was towards total vitamin A intake ( 42 to $68 \%$ for consumers). This is an important finding, as one third of South African preschool children are vitamin A deficient (Labadarios et al., 1995). Vitamin A in plant foods is present in the form of provitamin A carotenoids, mostly $\beta$-carotene. Provitamin A carotenoids achieve vitamin A activity when they are converted to retinol in the body. Dark-green leafy vegetables, yellow/orangefleshed vegetables, and yellow/orange-fleshed non-citrus fruit 
are good sources of provitamin A carotenoids. It is generally accepted that $6 \mu \mathrm{g}$ of $\beta$-carotene equals 1 retinol equivalent (RE) of vitamin A activity or $1 \mu \mathrm{g}$ retinol (FAO/WHO, 2001). This conversion factor is used in the South African food composition database that was used to convert food intake to nutrient intake. A study done by De Pee et al. (1998) quantified the effectiveness of dietary retinol sources, orange-coloured fruit and dark-green leafy vegetables in improving vitamin A status among children with marginal vitamin A status. The findings led the authors to propose that $1 \mathrm{RE}$ is equivalent to $12 \mu \mathrm{g}$ of $\beta$-carotene for fruit and $26 \mu \mathrm{g}$ for leafy vegetables and carrots, rather than the conventional conversion factor of $6 \mu \mathrm{g}$. FAO/WHO (2001) acknowledge that recent data in general suggest revision towards lower bioavailability, but until additional definitive data are available, however, their recommendation remains at a conversion factor of $6 \mu \mathrm{g}$.

The bio-availability of $\beta$-carotene in dark-green leafy vegetables seems to be lower than previously thought (De Pee et al., 1998). Nevertheless, cconsumption of cooked and pureed green leafy vegetables was shown to have a beneficial effect on improving vitamin A status (Takyi, 1999; Haskell et al., 2004; Haskell et al., 2005). A South African study showed that home-gardens that focused on dark-green leafy vegetables and yellow/orangefleshed vegetables improved children's vitamin A status (Faber et al., 2002b). Cooking oil was added during preparation of both imifino and spinach for all the children who consumed darkgreen leafy vegetables during the $5 \mathrm{~d}$ recall period. This will have a beneficial effect on improving vitamin A status because fat enhances carotenoid absorption (Jayarajan et al., 1980).

For children consuming dark-green leafy vegetables, these vegetables contributed 19 to $39 \%$ of total iron intake. Darkgreen leafy vegetables contain relatively large amounts of iron, but they also contain oxalates and phytates that inhibit the absorption of non-haem iron. The bioavailability of non-haem iron in plant foods is therefore low and the potential contribution of plant foods towards controlling iron deficiency in developing countries has been questioned (De Pee et al., 1996). Agricultural interventions to increase the supply and dietary intake of iron from plant foods are not popular. Instead, the production and consumption of animal foods are usually encouraged because of the high bioavailability of haem iron from animal foods (Ruel, 2001).

Promoting dark-green leafy vegetables may be difficult, as traditional food crops (e.g. green leafy vegetables) are often seen as the 'poor person's food' (FAO, 1997). Many people are not aware of the nutritional value of such plants and many may regard them as inferior (Steyn et al., 2001b). Lack of popularity and unavailability were given as possible reasons for the low consumption of indigenous vegetables (pumpkin leaves 3\%; dried green cowpea leaves 3\%) observed among college students in Limpopo Province (Mbhenyane et al., 2005). Campaigns promoting these vegetables should focus on the younger generation, as they have less knowledge regarding wild green leafy vegetables (Modi et al., 2006).

Modi et al. (2006) stated that cultivated lands are more suitable for the growth and development of wild leafy vegetables, and the availability of wild leafy vegetables could therefore be enhanced by cultural practices associated with crop management. Liphadzi (2006) of the Agricultural Research Council argued that production of wild leafy vegetables in home gardens or availability thereof in local markets would be advantageous. Water is one of the essential resources to ensure food production. Promoting the production and consumption of wild leafy vegetables is advantageous as these vegetables are relatively drought tolerant and grow on soils of limited fertility (Shiundu, 2002).

In conclusion, dark-green leafy vegetables made a significant contribution towards total nutrient intake of two- to fiveyear-old children for several of the micronutrients. This contribution can potentially be increased should these vegetables be consumed more frequently and by a larger proportion of the children. This can be achieved through appropriate promotion and nutrition education programmes, e.g. promote as nutritionally rich traditional green leafy vegetables.

\section{Acknowledgements}

The study was funded by the South African Sugar Association. We would like to thank the nutrition monitors, Bongi Duma, Nhlanhla Hlophe, Derick Mkhize, Lindiwe Msiya, Angeline Ndlovu and France Phungula, for recruiting the participants, completing the questionnaires and coding the dietary data; Ayanda Zondi for dietary coding; Lee-Ann Runcie for computerizing the data; and the caregivers of the children who participated in the study.

\section{References}

ALLEN LH (1994) Nutritional influences on linear growth: a general review. Eur. J. Clin. Nutr. 48 (suppl 1) S75-S89.

DE PEE S, WEST CE, PERMAESIH D, MARTUTI S, MUHILAL and HAUTVAST JGAJ (1998) Orange fruit is more effective than dark-green, leafy vegetables in increasing serum concentrations of retinol and $\beta$-carotene in schoolchildren in Indonesia. Am. J. Clin. Nutr. 68 1058-1067.

DE PEE S, WEST CE, MUHILAL, KARYADI D and HAUTVAST JGAJ (1996) Can increased vegetable consumption improve iron status? Food Nutr. Bull. 17 (1) 34-36.

FABER M, OELOFSE A and BENADÉ AJS (1998) A model for a community-based growth monitoring system. Afr. J. Health Sci. 5 (2) 72-78.

FABER M, PHUNGULA M, VENTER S, DHANSAY M and BENADÉ AJS (2001) A Home-Gardening Programme Focusing on Yellow and Dark-Green Leafy Vegetables to Improve Household Food Security and Undernutrition with Special Reference to Vitamin A Status of Preschool Children. Medical Research Council, Tygerberg. 23 pp.

FABER M, VENTER SL and BENADÉ AJS (2002a) Increased vitamin A intake through targeted home-gardens. Public Health Nutr. 5 (1) 11-16.

FABER M, VENTER S, PHUNGULA MAS, DHANSAY MA and BENADÉ AJS (2002b) Home-gardens focusing on the production of yellow and dark-green leafy vegetables increase serum retinol concentrations of 2-5-y-old children in South Africa. Am. J. Clin. Nutr. 76 (5) 1048-1054.

FAO (1997) Agriculture, Food and Nutrition for Africa. A Resource Book for Teachers of Agriculture. Food and Agricultural Organization of the United Nations, Rome. $412 \mathrm{pp}$.

FAO/WHO (2001) Human Vitamin and Mineral Requirements. Report of a Joint FAO/WHO Expert Committee. Food an Agricultural Organization, Rome. 286 pp.

HASKELL MJ, JAMIL KM, HASSAN F, PEERSON JM, HOSSAIN MI, FUCHS GJ and BROWN KH (2004) Daily consumption of Indian spinach (Basella alba) or sweet potatoes has a positive effect on total-body vitamin A stores in Bangladeshi men. Am. J. Clin. Nutr. 80 (3) 705-714.

HASKELL MJ, PANDEY P, GRAHAM JM, PEERSON JM, SHRESTHA RK and BROWN KH (2005) Recovery from impaired dark adaptation in nightblind pregnant Nepali women who receive small daily doses of vitamin A as amaranth leaves, carrots, goat liver, vitamin A-fortified rice, or retinyl palmitate. Am. J. Clin. Nutr. 81 (2) $461-471$.

INSTITUTE OF MEDICINE (1997) Dietary Reference Intakes for Calcium, Phosphorous, Magnesium, Vitamin D, and Fluoride. National Academy Press, Washington DC. 448 pp. 
INSTITUTE OF MEDICINE (1998) Dietary Reference Intakes for Thiamin, Riboflavin, Niacin, Vitamin B6, Folate, Vitamin B12, Panthothenic Acid, Biotin, and Choline. National Academy Press, Washington DC. 592 pp.

INSTITUTE OF MEDICINE (2000) Dietary Reference Intakes for Vitamin C, Vitamin E, Selenium, and Carotenoids. National Academy Press, Washington DC. 529 pp.

JAYARAJAN P, REDDY V and MOHANRAM M (1980) Effect of dietary fat on absorption of $\beta$-carotene from green leafy vegetables in children. Indian J. Med. Res. 71 53-66.

KRUGER M, SAYED N, LANGENHOVEN M and HOLING F (1998) Composition of South African Foods. Vegetables and Fruit. Supplement to the MRC Food Composition Tables 1991. Medical Research Council, Tygerberg. $160 \mathrm{pp}$.

LABADARIOS D, STEYN N, MAUNDER E, MACINTYRE U, SWART R, GERICKE G, HUSKISSON J, DANNHAUSER A, VORSTER HH and NESAMVUNI EA (2000) The National Food Consumption Survey (NFCS): Children aged 1-9 years, South Africa, 1999. Department of Health: Directorate of Nutrition, Pretoria. $1046 \mathrm{pp}$.

LABADARIOS D, VAN MIDDELKOOP AM, COUTSOUDIS A, EGGERS RR, HUSSEY G, IJSSELMUIDEN C and KOTZE JP (1995) The South African Vitamin A Consultative Group. Children aged 6-71 months in South Africa, 1994: Their anthropometric, vitamin A. iron and immunization coverage status. South African Vitamin A Consultative Group, Isando. 335 pp.

LANGENHOVEN ML, CONRADIE PJ, WOLMARANS P and FABER M (1991a) MRC Food Quantities Manual, 1991 ( $2^{\text {nd }}$ edn.). Medical Research Council, Parow. 213 pp.

LANGENHOVEN ML, KRUGER M, GOUWS E and FABER M (1991b) MRC Food Composition Tables, 1991 ( $3^{\text {rd }}$ edn.). Medical Research Council, Parow. 245 pp.

LIPHADZI K (2006) Native African vegetable growers had the right idea. Science in Africa. <http://www.scienceinafrica.co.za/2006/ march/african\%20vegetable.htm> (Accessed on 19/06/2006).

MBHENYANE XG, VENTER CS, VORSTER HH and STEYN HS (2005) Nutrient intake and consumption of indigenous foods among college students in Limpopo Province. S. Afr. J. Clin. Nutr. 18 (1) $32-38$.
MODI M, MODI A and HENDRIKS S (2006) Potential role for wild vegetables in household food security: a preliminary case study in KwaZulu-Natal, South Africa. African Journal of Food Agriculture Nutrition and Development 6 (1) <http://www.ajfand.net> (Accessed on 04/09/2006).

NESAMVUNI C, STEYN NP and POTGIETER MJ (2001) Nutritional value of wild, leafy plants consumed by the Vhavenda. S. Afr. J. Sci. 97 51-54.

OELOFSE A, FABER M, BENADÉ JG, BENADÉ AJS and KENOYER DG (1999) The nutritional status of a rural community in KwaZuluNatal, South Africa: the Ndunakazi project. Cent. Afr. J. Med. 45 (1) 14-19.

RODRIGUEZ-AMAYA DB (1999) A Guide to Carotenoid Analysis in Foods. International Life Sciences Institute, Washington DC. 64 pp.

RUEL M (2001) Can Food-Based Strategies help Reduce Vitamin A and Iron Deficiencies? A review of recent evidence. International Food Policy Research Institute, Washington DC. 63 pp.

SHIUNDU KM (2002) Role of African Leafy Vegetables (ALVs) in alleviating food and nutrition insecurity in Africa. Afr. J. Food Nutr. Sci. 2 (2) 96-97.

STEYN NP, BURGER S, MONYEKI KD, ALBERTS M and NTHANGENI G (2001a) Seasonal variation in dietary intake of the adult population of Dikgale. S. Afr. J. Clin. Nutr. 14 140-145.

STEYN NP, OLIVIER J, WINTER P, BURGER S and NESAMVUNI C (2001b) A survey of wild, green, leafy vegetables and their potential in combating micronutrient deficiencies in rural populations. S. Afr. J. Sci. 97 276-278.

TAKYI EEK (1999) Children's consumption of dark green, leafy vegetables with added fat enhances serum retinol. J. Nutr. 129 15491554.

WARREN GL (2001) Vegetables: dark-green leafy, deep yellow, dry beans and peas (legumes), starchy vegetables and other vegetables. Institute of Food and Agricultural Sciences, University of Florida. Website: http://edis.ifas.ufl.edu/pdffiles/HE/HE93700.pdf (Accessed on 18/04/2007),

WHO (1999) A Critical Link. Interventions for Physical Growth and Psychological Development. World Health Organization, Geneva. 79 pp. 